\title{
THE CONCEPT OF LAW AND JUSTICE
}

\section{Ilir QABRATI}

University “Ukshin Hoti” Prizren, Faculty of law.ilirqabratil@outlook.de

\section{Article history:}

Submission 07 August 2020

Revision 12 September 2020

Revision 25 September 2020

Accepted 30 November 2020

Available online 31 December 2020

\section{Keywords:}

Law,

Justice,

State,

Society and Norms.

\begin{abstract}
A b s t r a c t
From the views and changes that have followed the dynamism of our society, undoubtedly, law and justice have played a crucial role as a very abstract term that has been consumed almost from the first beginnings of human society to our modern days. Beyond the events and circumstances that societies in the past have had and organized by defining and choosing the way of life, and often times the right has been personalized by a certain group of people, or by a military division that has given rights and has created justice, in certain interests and for personal and charismatic purposes it has been denied a certain part of society, and has often been deformed in scandalous ways by reflecting, on the fact that the giver of this right has often been pointed out to be the man, but this convulsion in no case has lasted long, and often this theory has remained unrealized, reflecting that right is something natural and that the individual gains at the moment of birth and enjoys it to death, this divergence and complexity of the way of perceiving the law has often resulted in wars and the acquisition of this vital right.
\end{abstract}

Through this paper we will draw philosophical and legal paradigms, analyzing from a retrospective way of the application of law and the applicability of justice, as an important mechanism of regulation of social relations. Law and justice have a common path of development, one by regulating the way of life of the people, that is, by issuing norms and the other by giving justice to the relative complexity and cohesion of interpersonal relations.

\section{Introduction}

The topic chosen for analysis, which is entitled the concept of law and justice, basically contains an extension of a concept which addresses both from a philosophical and legal point of view, and above all expresses the abstract concept that our consciousness judges in relation to a right, or share a justice if not from an institution, then anyway from our private life, to the separation of justice from our institutions.

This topic from the philosophical treatment in its background, has drawn deep thoughts by analyzing those of philosophers and ideators who have dealt with this issue from the past to the present day, and at the same time I have drawn paradigms of a personal judgment regarding justice.

As far as the legal side is concerned, we have dealt with a part of the legal structure which this right finds its basis only in written leagues, and which for each of the citizens it becomes mandatory in terms of its observance. And it is precisely these rights that maintain our balance in a society.

\section{On the Law}

When we talk about law, we must return to the vital origin of its history, the philosophical point of view of law as the basis of philosophical and scientific articulation where it is rightly called that the subject of philosophy is law itself, therefore the study of law has never been easy, and in particular Kant's view when synchronizing the idea of disregarding jurists, and between the lines he emphasizes that law is still being sought, by philosophers, jurists, and the individual.

Regarding the law from the philosophical point of view, and using the a priori method I am involved in some names starting from the one which is evident "the right", through this name we understand the norms that are sanctioned by the state or with a formal-legal definition, we can understand: That norms are a set 
of rules, that society has regulated its behavior, through these rules, and for violators of these norms sanctions are applied, or the democratic and legitimate apparatus of the state, thus the applicability of legal norms (Osmani, 2004). Among other things, we have the opinion of the famous philosopher A. KAUFMAN, where according to him the right has its existence, it is positive because it is created through the law, it also has its own brand or content, it has justice, regularization (Lukiq, 2008). It is an opportunity of logical understanding when human consciousness attributes to the creation of a norm with rule content when it modifies the relations in a certain society, in different forms as for each case with special satributes gives a certain solution.

We also find another concept on law in the great philosopher $\mathrm{H}$. Kelzen, where he says that positive law is the right itself, those legal norms, which are quite concretized, and actualized can be accurately recognized and applied. So it is about norms that are understandable, with clear meaning, in determining human behaviors (Kryeziu, 2011).

Contrary to these concepts, which are confronted from different points of view and currents of thought, where we find almost a greater part of the thoughts that match each other considering the right as a norm itself, but a facticist theorist of South America, Carlos Kosiji, develops the second realistic factual option, and according to him, law is not the norm, but really the behavior of people and this not only of official persons, and other bodies but is of all ordinary subjects of law. He presents this type of distinct phenomena by proclaiming the following phenomena: IDEAL, NATURAL, CULTURAL and METAPHYSICAL.

The law-the right Kaufman calls law, and according to this concept he says that people should debate about how fair it is, whether it is a good, fair law, and try to give the best in the perfection of the law. To understand law in a realistic relationship, there is another example, typical when law is attributed to human consciousness:

$$
\text { Law }+ \text { court }+ \text { case }=\text { solution }
$$

\section{The Law}

So through the right (law), which has its own existence, in the strict sense that law is a normative phenomenon, while norm is a mandatory social rule for the behavior of people brought (or) sanctioned by the state, respectively e protected by the state apparatus. It means that the social rule for the behavior of people can also be created by the state, when it is brought by the competent state body, or the state to sanction certain social norm (moral, customary) that exists. The power and importance of the legal norm stems from the fact that it is protected by the state apparatus. This fact also distinguishes it from other social norms, respectively their implementation is not provided by the state. So in the formal-legal sense this different norm is also called law. Law is a lower legal act than the constitution, which regulates a general sphere of relations in a given society.

Regardless of how the legal norm is expressed (law, bylaws, custom), it consists of three elements or constituent parts: Hypothesis, Disposition, and Sanction.

The hypothesis is that part of the norm that provides: the circumstances in which the legal norm operates. It is a precondition, without the existence of which the legal norm is not implemented, does not apply.

The disposition is that part of the norm that provides for the content of the rule of conduct itself. The sanction provides for a restrictive measure, in case of non-implementation of the norm. (Gurakuqi, 2009).

\section{The Court}

The court is a governmental institution, with the authority to adjudicate legal disputes between the parties and to administer justice in matters pursued formally and those with individual initiation. Courts treat all persons equally and no one can be discriminated against on the basis of race, color, sex, language, religion, political or other opinion, national or social origin, connection with any community, property, economic, social status, sexual orientation, birth, disability or any other personal status (Law No. 06 / L-054 on the courts). This connection between the law and the court leads us to understand that initially human actions are provided by legal norms and they are sanctioned by law, before they go to trial, this also means a legitimate relationship of state authority, legitimizing his actions in restricting human freedom if it conflicts with existing laws or norms.

\section{The Case}

All those actions that violate the good of a person or the life of people in a certain society, and face legal norms, become the object of sanctions that the state has imposed on those who violate these legal rules, based on the fact these actions are sanctioned by the state and as such, are also provided by law. So, the case is an interaction of the interpersonal subjectivity itself that affects, an action in society which action is illegal, or hits a legal good, and exactly the creation of a case, affects the Law + court when an action has caused the case or has violating the norms or laws in force, and fulfilling the responsibilities, will be ascertained with 
the development of the procedures exercised by the institutions and the norms in force of the state.

\section{The Solution}

The settlement is an effective action and result, which comes as a result of an activity related by the court, for a certain issue that is now subject to review in the procedure, of a human action and ends with a formal legal action, written decision thing which fulfills the formula listed above: Law + court + case $=$ solution. Law is driven by two main factors from the real world: the one (anthropological) factor and the social (sociological) factor. One is a free factor and a creative being who, by his actions, limits or impairs the actions of others. Being free in his actions, he decides according to his own motives what he will do, the motivation does not deny his freedom, but only puts him into action.

Human freedom is a motivating condition for the existence of social norms, and even law for two reasons: First, man without norms would not know how to behave, the non-existence of these norms would reflect another reality in our society. Second, the free man would not take proper care of the general social interest, and would harm it with his own conduct, so that all social norms and even these legal ones are a kind of instruction on how man should act but at the same time, it is also a means of society to put pressure on me to act in the general interest (Lukiq, f. 76). Life practices and the very history of legal norms have often violated the will of a majority, but in most cases this violation of free will has been done with deliberate reasons to protect the basic and elementary values of human existence such as: internment from the state, punishment of family members, imprisonment in the insane asylum, or quarantine for infectious diseases. In these most flagrant cases of the disappearance of free will, you can no longer hold the human being accountable if it can be called that. Unlike Rousseau, Milli does not give much weight to social circumstances. The quality of free will in him means that "the will, unlike other phenomena, is not largely determined by the past, but dictates itself " (Ruso, 1998).

Since we have managed to conceive of freedom and will as one of the essential elements of the norm, now we cannot avoid the ethical element which is reflected in almost every part of our lives, this expresses a way of socio-cultural awareness, which a society has for norms. To come to the notion of ethics, the prominent and lavish representative of this powerful current is Spinoza, who defines ethics as: A mental, and spiritual, individual and common exercise, and as such it cannot "read" but only to live. (Spinoza, 2015). This would affect a relationship between norm and consciousness, social where the observance of legal norms determines the level of social education, so the higher the human awareness, the lower is the violation of legal norms. As for the influence of human rights, it affects many directions, not only disciplining and socializing it, subjecting it to society, but also seeking to adapt to it. On the other hand we have the state that represents and constrains it, while on the other hand we have free society, based on its own consciousness. Conflicts of interest, and the separation of man from society, have been necessary to represent the state.

So far we have discussed the positive law and its relationship with man, now we will see the right in the objective relationship, we encounter the first thoughts about the objective law since ancient Greece, this phenomenon has been developed by sophists started by Hippie, Antifooni, they have claimed that the violation of natural law is harmful, for the offender himself who cannot avoid the bad consequence, while the violator of the positive right can succeed in avoiding the self-created consequence. Natural law has its options, starting from the opinion that natural law is a kind of law of experience, or the right of God, because it is the true creator of nature, whether of man or human society. The most important feature of natural law is that it is rather the right of experience, (which means an object which has never been subject to the process of experience, such as God). From a political and legal point of view, it is the result of the struggle for positive law, as a political tool in the struggle for change in political relations in a society, and that the content of law varies, depending on the real social circumstances they use as a tool in political warfare (Lukiq, 2008a).

We find views on natural law in Christian times in Toma Akvinsky, in his work "Suma of Theology", the right in the narrow sense, connects with man as one of the means by which God influences man to do good deeds. According to T. Akvinsky, there are four kinds of law: Eternal Law, the Law of Nature, the Human Law, and the Laws of God (Lukiq, 2008b).

Eternal law is the law according to which the whole universe is governed, which only God knows, as the creator of everything in the world, because with the creation of the world he has also created its laws.

The law of nature is the participation of the eternal law of mindreason, this law according to T. Akvinsky (1938) can be understood in two ways: either in the subject who measures it, and if the subject is regulated and proportioned, on the basis of that who participates in the rule of regulation or measure.

According to T. Avinsky (1938), human law derives from natural law, if it is contrary to it, it is not a law, only a shadow of the law, an evil law, the law can be distinguished from the natural law by 
two natures: first, the conclusions from its own principles, even as the closest definition of general notions.

As well as the law of God, which is necessary because man has to fulfill in one way his supernatural purpose, the other world, the fulfillment of which is done by law, because man errs in his attitudes, so he needs strong support in the law of God (Lukiq, 2008).

All these laws in the past have been powerful tools that have regulated the way of life in most of the countries where the church has been an institution or a state in terms of the applicability of customary and written law. As for the conception of law by the Romans, they have made many definitions of law, one of the philosophers Celsions defines right, "ars boni et aequi" (as the art of good and law), so as can be seen that in the first period of its development, it had a religious character because it has been interpreted by ecclesiastical clergy.

The Romans used the term "ius" to describe the totality of legal norms that applied to state-sanctioned social regulation. "Ius" therefore applied Roman law, in the objective sense as a system of norms, which regulated various human behaviors, while in the subjective sense, it consisted of two authorizations, or opportunities for the subject of law:

- $\quad$ First, each entity personally performs certain actions to meet its interests in accordance with legal norms.

- The second is to ask the obligated subjects to perform or not to perform a certain action.

- Objective law is a necessary condition for subjective law, without which the latter cannot be applied (Kryeziu, 2017) .

In addition to the term right to the Romans, the term "leges" or law was used, which meant laws and was distinguished from law, as it constituted a separate law, throughout the justice system. Also in the first period of development, the main role was played by legal rules of a religious nature, we should also mention the customs, which were unwritten rules that were gradually born in society generation after generation, in a relatively long time, and since cases of non-compliance with them caused social sanctions (Kryeziu, 2017).

Law represents its existence from the very beginning of social organization, achieving its moderation and advancement since the twentieth century VII BC at that time the Roman state from a city of little importance, passed into a state, then into a very great persecution, creating and bringing about a revolution in terms of reform and the creation of a vital foundation for the system which today operates in the world, thanks to the Roman state.

\section{The Continuity of Law and Justice}

Right and justice, in everyday life each of us and that with full mouth expresses a good, righteous man, that justice is in the soul, these are stereotyped satributes, which every individual thinks from the aspect of consciousness. However, taking into account the complexity of the issue, jurists and most people from the ordinary world consider it a collection of norms that are sanctioned by the state through the democratic mechanism, the law has its own existence and is positive, because it is created through law, it also has its own brand, applying all these rights establishes justice or regularization in a given society. Law and justice live in a cohesion between each other, creating opportunities and another justice at a certain time. The law itself is what the authorities do in case of disagreement, and through this right it provides what the court will do in case of resolving a certain dispute.

According to Socrates, it is necessary to discover the essence of justice and injustice, and at the same time to clarify what is the source of justice and injustice, and from this fact must be started and sought, the perfect paradigm or model, which includes states and people, in to the extent that they are right, it is not important that perfection be fully realized. It would be crucial to have something perfect, to measure real states, and people (Malnes \& Midgaard, 2007).

Law is the primary norm that determines sanctions, which is created by human consciousness or we can call it a positive right. To go deeper into the subjective aspect, it is that the subjective right is a concrete right, which belongs to a certain person, as opposed to the objective right where, as we have already mentioned, it is a set of norms for the regulation of social relations, the implementation of which is provided through the implementation of the sanction. From all the above, the state has set norms that regulate how we should behave in society, restricting us and allowing us a right that is forbidden to another and allowed to us. As a right guaranteed by a positive right for every individual is the right to life, the right to property, and at the same time a justice is created that implies the will of the people, that everyone should be given what belongs to them. Natural law has a different approach to positive law, which we can call ideal, which is found in human nature as a rational being, it is a set of rules, which nature dictates to human reason.

Violation of natural law is detrimental to the offender himself, who cannot avoid the consequences of evil, and in positive law he can succeed in avoiding the consequences. So, are we able to accept the basic principles of justice, according to Ulpian, by defining justice in three main pillars: to live with honor, not to harm the other, and to get what belongs to us? It is precisely these 
virtues that are part of a high interpersonal awareness, that by respecting these revisions we manage to avoid disagreements and norms as such would not have been violated.

Justice is a troublesome feature not only for the individual but also for the states, from a common point of view it is something between the greatest good (that is, to do injustice without being punished), and the greatest evil (that is, to suffer injustice without revenge for it) (Malnes \& Midgaard, 2007a). In this case, justice has been raised to the highest pedestal, which serves as an orientation for both the legislator and the judge, to use the instruments for the purpose of administering justice, which in this case constitutes the highest rank on the administration of justice. These elements as well as these principles must be used by everyone to be able to, if society believes in such a role, decide correctly and on the basis of moral and legal principles as well as divine principles and justice, if it can be called so with in order for law as a social element to be in coherence with justice. The embodiment of these two premises would certainly give a basic meaning to the notion of law and justice in general.

\section{Conclusion}

The reflection of the paper is a trend which reflects on a specification on law and justice, taking into account how broad and difficult the topic of law is. We have managed to highlight some of the features and concepts of many philosophers, and continuing with the intertwined thoughts of both the legal and sociological worlds, seeing the nuances and perceptions of factual theories with a wide range of elaboration and its interconnection with justice, as two virtues that have almost followed humanity, from the first beginnings of tribal creation and regulation, to the modern state.

The topic in question has tried to refresh the thoughts on law and justice, as well as the continuity of these two issues in our society, in the scientific spirit and based on the literature document.

In the first part of this paper we have analyzed what is right, the first thoughts on the foundation of this notion, as well as its existence as a necessity in regulating our social relations. In particular, we have managed to conceive that law and justice are in a constant coherence when one, according to the philosophical and formal-legal concept, creates norms, and the other gives justice at a certain time, and for each individual case.

In conclusion, we can draw conclusions about the importance of the right where the most important part of our rights that we enjoy today are part of a legal system, otherwise called the norm, and the rest justice where both together they create a lasting peace in the relationship and complexity built and the regulation of relations in a given society.

\section{References}

1. Akvinský, T. (1938) Theologická summa I-II. Redigoval P.Emilián Soukup. Olomouc: Lidové závody tiskařské a nakladatelské.

2. Gurakuqi. R. (2009) Introduction to Public Law. Camaj-Pipa-Tirana. p.64

3. Kryeziu. K. (2011) Introduction to the Theory of Law. Pena- Prizren. p.20

4. Kryeziu. K. (2017) Roman Law. Pena - Prizren. p.17

5. Lukiq. R. (2008) Philosophy of Law. Prishtina. p.36

6. Malnes. O. \& Midgaard. K. (2007) Political Philosophy. Prograf-Prishtina. p.25

7. Osmani.I. (2004) The Beginnings of Law. Grafo BeniBotus Council of the University of Prishtina p.7

8. Ruso. J. J. (1998) Social Contract, Luarasi Publishing House. Tirana. p. 21

9. Spinoz.a B. (2015) Ethics. Point without surface Tirana. p.328

10. Law No. 06 / L-054 on the courts. Prishtina.. p.7. Available at: https://gzk.rksgov.net/ActDocumentDetail.aspx?ActID=18302 